\title{
Forestry and pork's industry: Sustainable development in southern Brazil
}

\author{
Luiz Panhoca ${ }^{1}$, Luis Lopes Diniz Filho ${ }^{2}$ \\ 1. Accounting Department, UFPR/ Universidade Federal do Paraná, Brazil \\ 2.,(Department of Geography, UFPR/ Universidade Federal do Paraná, Brazil
}

\begin{abstract}
This paper proposes to study the alternatives for the rural population of the southern Brazil, in these beginning of the XXI century. When forestry is implemented we can observe the degradation of quality of life indicators (health, education and income). The multi activity of the small producer is replaced for the so called culture of abandonment. The issues addressed in this study are (i) is forestry an activity that leads to the impoverishment of the region? (ii) will the southern Brazil be "reached" by forestry? (iii) do the traditional pork's economic activity will be displacement by the forestry industry? To answer these questions the hypotheses formulated are (i) there is an inverse relationship between the HDI and forestry and pork's activities, (ii) There is a direct relationship between pork's activity and forestry, and (iii) forestry is replacing the traditional economic activity. Data analysis showed is not possible to study the production in an aggregated manner.
\end{abstract}

Key words: Economic activity, alternatives to forestry, smallholders.

\section{Introduction}

This work reflects of the potential income of the rural population living in southern Brazil. When conducting this study we found a level of quality of life and economic profile characteristic: small farm, multi activity basically subsistence farming, milk, and chicken or pork and planting cereal livestock for consumption. Another finding is the lack of availability of labor and family participation in the production of the property [1], [2]. Here the landscape looks so irregular that there are extensive plantations and properties are characterized by irregularity of relief [3], [4], [5], [6].This property profile is also observed in the Ribeira Valley in Paraná (Brazil) [8], however the Human Development Index (HDI) of the region is significantly lower [7], [8], [9]. The question then posed is: Forestry will displace the pork's farms and marginalize their owners?

The global economic crisis that occurred in the years 2008 and 2009 led to disastrous consequences for small farmers. According to Adams and Korten, in Brazil southwest (Santa Catarina), previous crises shifted the production of beef for the Brazil Midwest (Mato Grosso) region [9], [10], [11].In the mid-2000s, we note the progress of planted forest industry in southern Brazil. The wood industries at first settle on the border between Brazil and Uruguay and Rio Grande do Sul, and at various times in Santa Catarina and Paraná [12]. However the idea of approaching the subject focusing on the relationship between rural poverty and environmental degradation was dismissed at first given findings that the hypothesis of this relationship presents itself in the form of a trap or a vicious circle, and that improvements in socioeconomic conditions of farmers necessarily have positive impacts on the environment [13]. It also dismissed the explanation for the Theory of Critical exploration of regions that explore regions [14].

The issue to be resolved is not the capital in space, but the development of capitalism in space [14]. The state of Santa Catarina has the second best Brazil's HDI [15]. The western region of the state is composed of small farms, originated in the division of lands of the settlement of European immigrants and still maintains its customs and traditions survive and revenue from small farms and small agribusinesses [9], [16], [19], Analyzed by the focus of several current literature it appears that the effect of innovation continues to destroy the investment and skills of past work [18], [19], [20]. Similarly the World Bank has clear those times of crisis inhibited clear understanding of the functioning and outcome of interventions and programs [4], [21]. This constant innovation requires these actors constantly redefine their processes to generate value as evidenced [18], [22], [23].

Analysis of the South (Fig.1), in the period 1996-2006, shows the percentage change of land use, according to the main types of use. It is noticed that the use of land in general decreases for Brazil as a whole. During this period the area under forests and forests increases significantly for the South Region and decreases for other regions of Brazil [12]. 


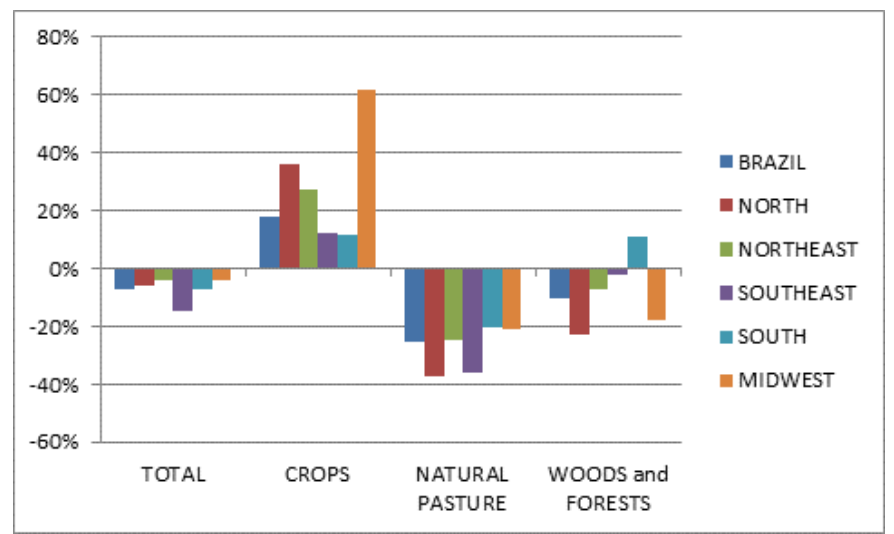

Figure 1 Change of use of land in Brazil [13]

Land use is the human use of certain land cover [24], and the term "change of land use" is the quantitative changes in the area (increase or decrease) of a given type of land use [25]. The change of use may involve the conversion or modification of its standard use and modify the same development system forming the landscape [23]. Aiming to think global and act local question possible alternatives for human development in these communities.

\section{Method}

The variables of quality of life, income and education were selected when doing research for work and Panhoca de Silva [26] and also in the work of Silva [9]. For the selection of variables related to planted forests, we used the Census of Agriculture 2006: Brazil and large parts of the Federation [12]. The data were processed using Analysis Conglomerates it is perceived in the Principles of Economics [26] which presents an analysis of the reasons of similar enterprises concentrate in certain locations [27]. The study of clusters is, among others, fundamental to policy makers and those who work with planning [28], [29], [30]. In the calculation of clusters, we divided the variables, reducing them to sets of similar elements and sets of heterogeneous elements distinct from the other elements of other groups [31], [32], [33].

It is also used in regression analysis which seeks to assess the impact of each explanatory variable and how effective the model is suggested. Search the relationship between a set of explanatory variables, metrics to evaluate and measure the influence of dependent variables and thus develop prediction models [34]. The unit of study cellular components are counties in southern Brazil and the results can be sensitive to the context and methods applied [21]. The statistical technique of cluster analysis is descriptive, not theoretical basis and not inferential. Although it has strong mathematical properties, has no statistical foundations and is not suitable for inferences of population characteristics from sample data [35]. This technique does not distinguish whether the variables are relevant to the study [33]. A regression does not necessarily establish a relationship of cause and effect. Shows a pattern or trend and is based on data analysis allows multiple possibilities of approaches [36], though not as Popper debases the principle of uniformity of nature [37].

This study aimed to evaluate possible alternatives to replace the traditional economy by smallholder forestry in the region west of Santa Catarina. The two processes are inseparable and interdependent [38], [39]. Embed this web of relationships is somehow possess a valuable, rare, irreplaceable and hardly imitable, i.e. it fulfills the conditions that, in the view of the resource-based view [40], [41], [42], are essential to generate and sustain competitive advantages. In general, focus on problems of large business units. Given these settings can identify the following specific objectives:

1. Identify how forestry affects the region.

2. Identify how pork's activity affects each group of variables rural component of human development.

3. Identify if the advancement of plantation wood will displace the pork's activities.

It is considered as a physical territory, geographically defined, characterized by multidimensional criteria, environment, economy, society, culture, politics and institutions, and a population that relate internally and externally through specific processes, where one can distinguish a or more elements that indicate identity and social cohesion, cultural and territorial [43], [14]. Import, it does not consider the definition of critical geography of the territory [44], [45]. It starts with the idea that systematic innovation leads firms to increasingly sophisticated levels of production and marketing, in markets large and dispersion [38],[46]. The territorial division of labor assigns elements and "privileged role" [47]. There non sociability of the individual one side, the other Society, from one side to the other species individuals [48]. Thus, this field informs that geography is a political process of historical construction [49], [50]. It is intended to represent these statements in categories and subcategories used in this paper. The definitions relating to forests are planted according to the FAO report 
[51]. In 2011 the gross value of forest production totaled US\$ 57.9 billion dollars. In 2010, forest products represent the fourth rank in the value of exports of Brazilian agribusiness. Paper, pulp, wood and articles thereof comprise this segment of agribusiness. Paper and pulp accounted for in 2010,73.0\% of the export value of the group called Forest Products by classification [52], [53].

Natural forests in Brazil account for $65.9 \%$ of the land area; agriculture $33.5 \%$ and $0.6 \%$ planted forests [54]. Brazilian conditions favoring forest productivity, reducing production costs. In temperate countries rotation is 50 years [55], [56], [57], [58].Brazil has about 6.8 million hectares of forest plantations, mainly eucalyptus and pine, representing $93 \%$ of total planted [59]. While ABIMCI talks about millions of jobs the government aims 615,900 direct jobs [59].

Facing the shortage of timber, has begun planting trees or forestry, but without the worry of proper management and the impacts of these practices. Most of the planting timber occurred after the 1950's and Exotic species were Eucalyptus and Pinus. The first plantations of Pinus canariensis, from the Canary Islands, occurred in Rio Grande do Sul, around 1880 [60], [61]. Eucalyptus was firstly planted in 1903 in Brazil, in the city of Rio Claro, São Paulo. The diversity of species and breeds not only came from the United States but also from Mexico, Central America, the Caribbean and Asia [61], [62],[64] [64].

Until 1965 the national forestry indicated 400.000 hectares planted with eucalyptus. From 1967 to 1982, were introduced exotic species of rapid growth and about one million hectares were planted with Pinus aiming to increase timber supplies to supply industry [65]. Projects should cover required by law, a certain percentage of the area with native species and Araucaria was one of the chosen [66]. Much of forests planted with Pinus spp., in the late twentieth century, are linked to the pulp and paper industries, boards, chipboards crowded, sawmills, veneer and resin processing industries, and are called "vertical companies [65].

Belatedly noted that some forest owners or vertically integrated companies do not just used the tax incentives of the 1960/70, and some use marginal lands for agriculture unviable and rarely show objective or appropriately structured management plans [65], [61], [67]. According to the United Nations Food and Agriculture Organization (FAO), Brazil is one of the top ten countries with plantations totaling 182 million ha. [68].

The western region of Santa Catarina (southwest region) was the last area to be colonized in south. Local traditional indigenous gradually been sought by mestizos and others who settled in search of livelihood. With the end of the Contested War, the region was ceded to companies of Rio Grande do Sul to colonization. As was covered in forests began logging [69]. The logging occurred since 1920, initially valuing the cedar and the scarcity of this, by 1940, it explores exhaustively pine [70].

Only there is an important population growth in the western region, in the 1970's, when it reaches $26.3 \%$ of the population of Santa Catarina. Thereafter, gradually decreases its participation in the following decades. In the period 2000 to 2004 was characterized as an evasion population, but in the years 1980 and 1990, there is a disconnection between farmers and agro-industrial complex. Also a growing difficulties faced by small producers. These transformations disaggregate the family farm, source of income and employment excluding a large contingent of people from the production process [71], [9]. On the national scene in the 1970's and 1980's, the agricultural frontiers were a most completely exhausted and cities are the great pole of attraction. Of the 110 counties of this middle region, $50 \%$ are made up of populations less than 5,000 and represent $15 \%$ of total population [12]. Conversely population concentration occurs in ten counties with $46 \%$ of the total population macro-region, in 2004.

Sadia-Concordia Company (pork and chicken) launched the in 1950 the 'Agricultural Development program'. An integration agreement or 'mutual' collateral production and marketing contracts occur in 1960's. [72]. This means that capitalism (i) subject places the logic of accumulation, (ii) is characterized by spatial selectivity, and (iii) the seats are specialized and hierarchical, but act in synchrony for a given economic system globally [14]. The creation of inequality is the result of the peculiarities that affect the historical movement of globalization of capitalism and diffusion of technical progress in the global economic space.

The development of the methodology follows the exploratory analysis process from the selection of the type of analysis to be carried out. As we sought to understand the region considered starting a macro positioning is decided by considering all counties in southern Brazil. The data from these counties are in the Agricultural Census [12] and the Atlas of Human Development in Brazil [73], [74], [75].

Another part of the problem formulation was constructed from interviews with local actors, documents, reports and observations in order to describe the impact of agribusiness timber, population and landscape. This construction took place following the logic: problem, context, subject, lessons learned [76] and was effective from semi structured interviews with actors in the Ribeira Valley, Paraná, Mato Grosso do Sul and Santa Catarina. 


\section{Analysis}

The analysis covers 1188 counties and counties in the southern region 399 in Paraná (PR), Santa Catarina (SC) 293 and 496 in Rio Grande do Sul (RS) An initial analysis of the data indicates a distortion of two counties, Bombinhas (SC) and Esteiro (RS) that were not considered in the study. The productive area presented by counties ranges from a maximum of 648.023ha (hectare) in the county of Alegrete - RS, to a minimum of 315ha in Balneario Camboriu - SC [13].

Counties forestry producers were non-symmetrical. Note that the cities do not produce the same kind of wood. It appears the number of 458 missing cases, (38.6\% of all counties), when analyzing the set of production forestry. Note that the density distribution of the production of the counties of Rio Grande do Sul is larger while producing counties are in greater number in Santa Catarina. In another group of variables the production of traditional economics, poultry, eggs, milk and pork, characteristics of the southern region, also observed a discontinuity of production with some counties appearing in a non-normally distributed invalidating the statistical analysis of economic activity as a traditional single variable. The canonical analysis initially adopted as a statistical analysis tool was discarded from these findings.

Counties producing trees form a cluster distinct spatial distribution; it is not possible to consider the mass of planted forests (forestry) as a single set. Given the finding is to individually assess each of the variables considered in this study.

\subsection{Analysis of the counties producers of eucalyptus}

The distribution of the eucalyptus culture in the southern is not uniform as can be seen in Fig. 6 and Fig. 7. The concentration of cases occurring in Rio Grande do Sul and Santa Catarina then, Paraná with lower incidence. The density distribution of eucalyptus in the south is not normally distributed.

For cluster analysis if checks for 1160 counties. The results of hierarchical cluster analysis showing a choice of five clusters considered in selecting choice of 3 to 20 .

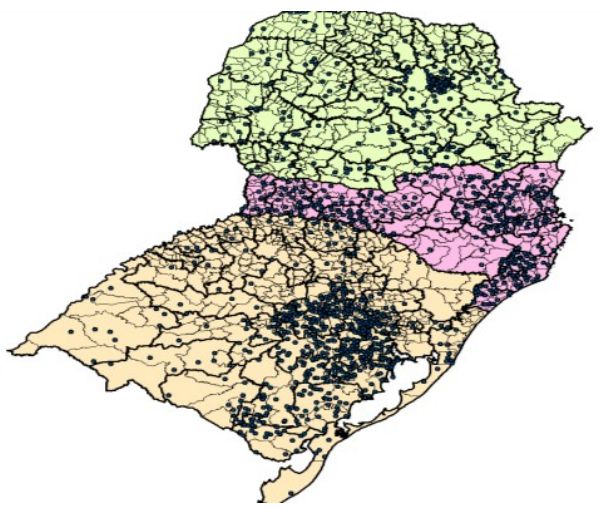

Figure 6 Distribution Eucalyptus (EU) - southern Brazil [85] [1 Dot $=1$ Million Trees $]$

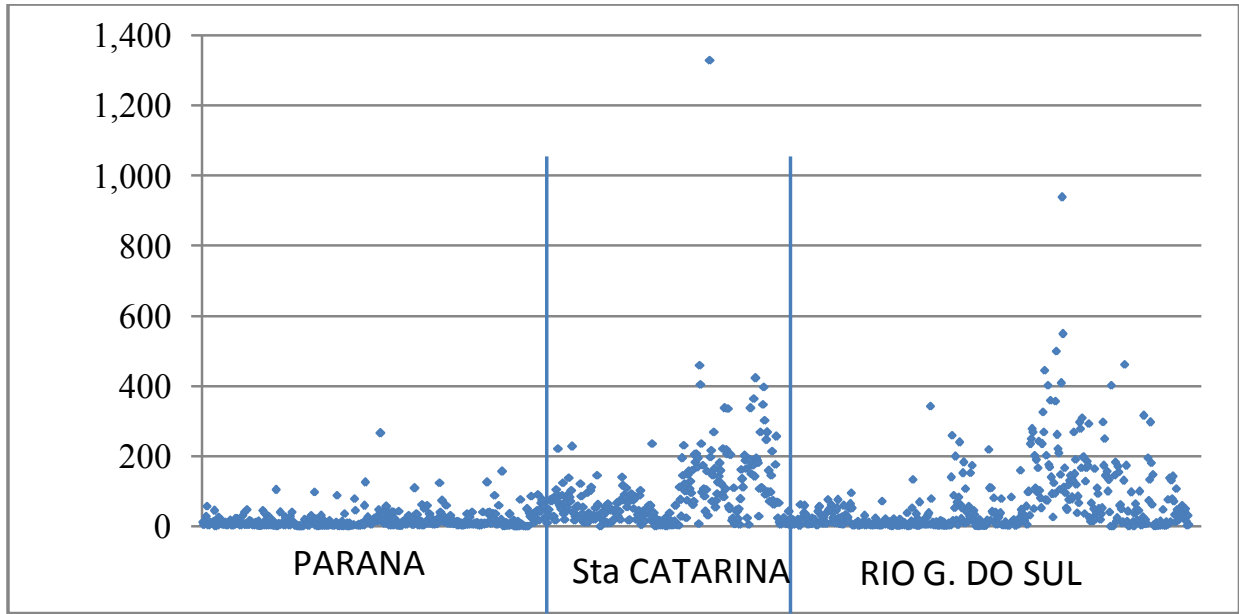

Figure 7 Densities by counties - Eucalyptus (EU) - southern Brazil 
The result of the analysis considering non-hierarchical for 5 clusters shows 27 cases and 926 missing cases considered production not significant and relevant 233 cases that were part of the correlation analysis with development indicators, 11 were located in Paraná, Santa Catarina and 112 in 110 Rio Grande do Sul

Correlation analysis between the cases of producers of eucalyptus (233 counties) and development indicators (HDM, HDI Income and HDI-Scholarity) resulted in 131 valid cases and 8 cases missing. The counties with significant density production, discarded test hypothesis for the lack of correlation values were HDIM: Lagoa Bonita do Sul, Canudos do Vale, Coqueiro Baixo, Pedras Altas, Forquetinha, São José do Sul, Coronel Pilar, Arroio do Padre, all those in Rio Grande do Sul.

The linearization of output density data eucalyptus follows an exponential function and linearization data for selected cities HDIM suggest a polynomial function. The test result correlation between eucalyptus production and development variables Fig. 8 shows itself not consistent for any of the variables studied, which confirms the hypothesis $H_{0}$ of no correlation.

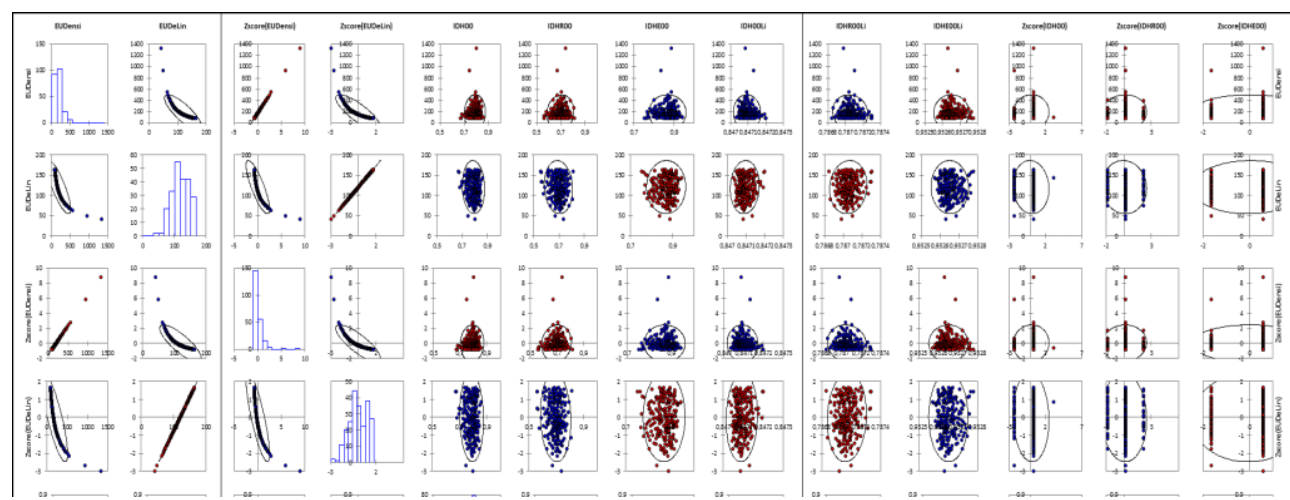

Figure 8 Results of correlation indicators of HDI and development

\subsection{Analysis of producing counties Pynus (PA)}

The distribution of pynus (PA) culture in the south is not evenly distributed as can be seen in Fig. 9 and Fig. 10. The concentration of American pine has little impact in Rio Grande do Sul where the presence is noticed on the border with the state of Santa Catarina. Note the marked presence in Santa Catarina and Paraná lower. The density distribution in southern pynus (PA) is not normally distributed. For the cluster analysis is verified and existence of 978 counties. The results of hierarchical cluster analysis showing a choice of six clusters considered in selecting choice of 3 to 20 .

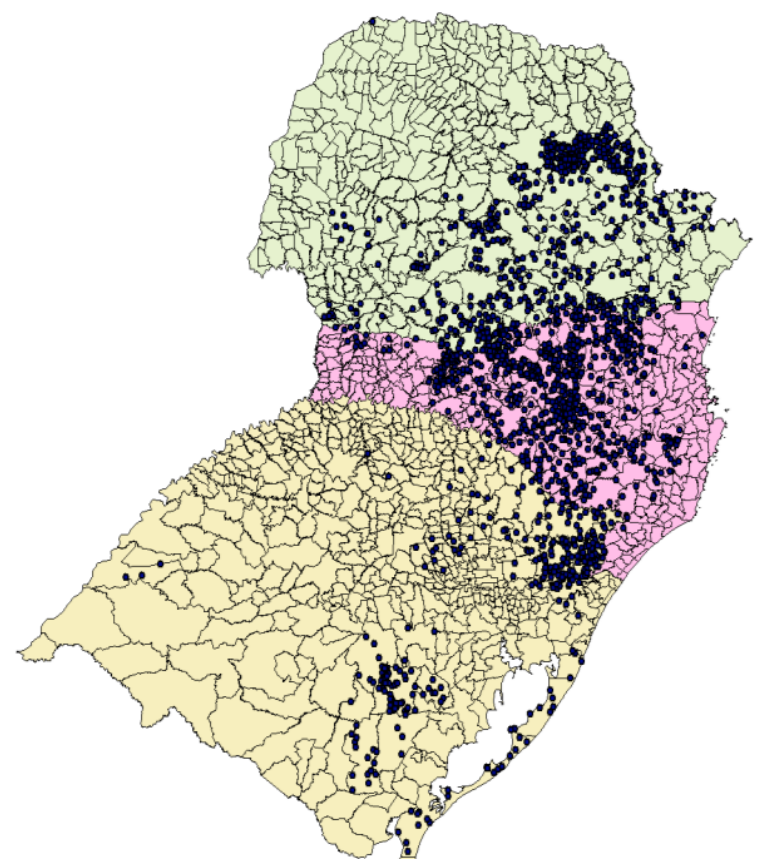

Figure 9 Distribution of Pynus - southern Brazil [85]

[1 Dot $=1$ Million Trees $]$ 


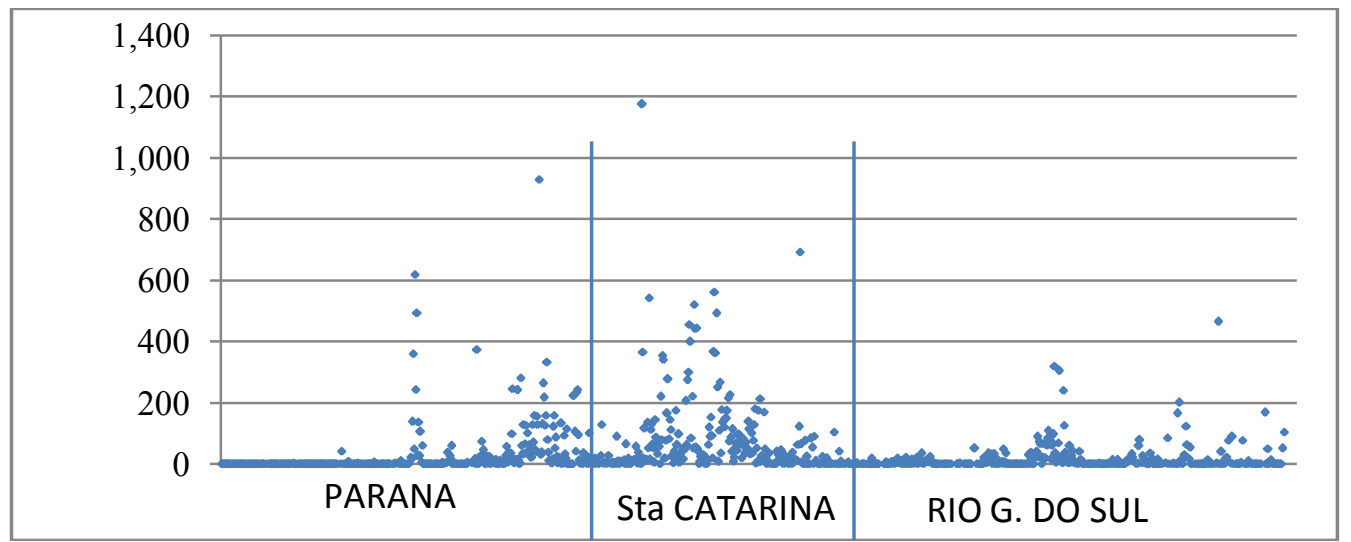

Figure 10 Densities by counties - Pynus - southern Brazil

Correlation analysis between counties producers of American pine and development indicators (HDI, HDI-IncomeandHDIEducation)116casesconsideredvalidand23missing.

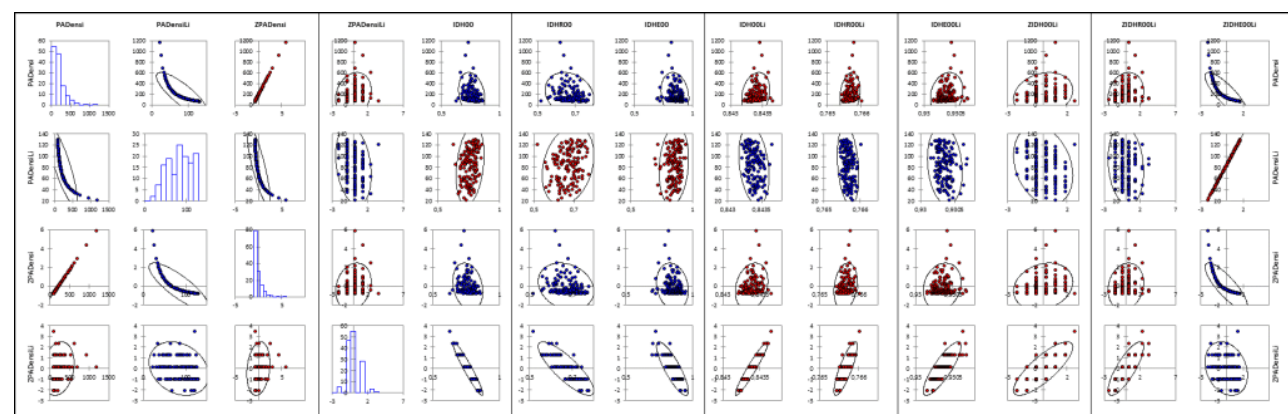

Figure 11 Result of correlation pork'sand Development Indicators

The linearization of the data density of pine American production follows an exponential function and linearization of HDI data for selected cities suggest a polynomial function. The test result of the correlation between production of American pine and development variables Fig. 11, shows up not consistent for any of the variables studied, which confirms the hypothesis $\mathrm{H}_{0}$ of no correlation.

The crossing of development indicators did not confirm the hypothesis of correlation with the variables forestry nor with the traditional economic activities. Actually what is happening is a dependency of exports Fig. 12. The dependence on exports of primary products is high and unchanged. Their values remain around $47 \%$ in 1990 and $46 \%$ in 2005 .

\subsection{Analysis of producing counties pork's (SU)}

The distribution of pork's farming in the southern region is not uniform as can be seen in Fig.1 and Fig.2. Concentration of cases occurs in Rio Grande do Sul and then in Santa Catarina and Paraná. For the analysis of conglomerates we check 1171 counties as shown in Table 1 . The result of the hierarchical cluster analysis and shows that the choice of 5 conglomerates. The result of non-hierarchical cluster analysis of 5 shows 15 missing cases and 969 cases considered not significant production. Table 2 shows that of the 202 relevant cases that were part of the correlation analysis with the development indicators, 20 were located in Paraná, Santa Catarina and 82100 in Rio Grande do Sul. 


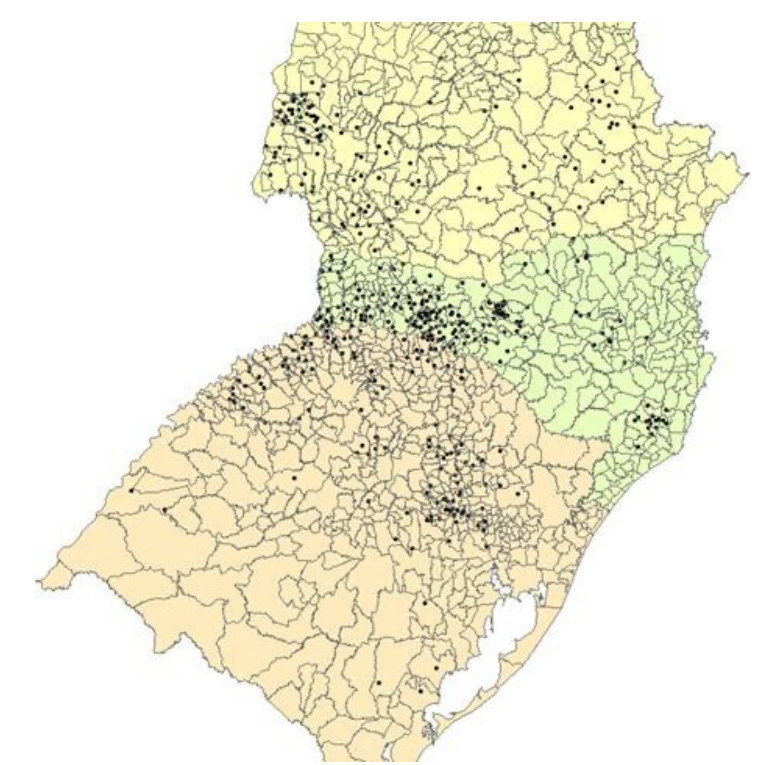

Figure 12 Densities by counties - porks - Southern Brazil $[1$ dot $=30.000$ animals $]$

TABLE 1 - PORK'S CASES

\begin{tabular}{c|c|c|c|c|c}
\hline \multicolumn{2}{|c|}{ VALIOS } & \multicolumn{2}{c|}{ MISSING } & \multicolumn{2}{c}{ TOTAL } \\
\hline $\mathrm{N}$ & $\%$ & $\mathrm{~N}$ & $\%$ & $\mathrm{~N}$ & $\%$ \\
\hline 1171 & $98,7 \%$ & 15 & $1,3 \%$ & 1186 & $100,0 \%$ \\
\hline
\end{tabular}

TABLE 2-NUMBER OF COUNTIES

\begin{tabular}{l|c|c|c|c}
\hline & PR & SC & RS & TOTAL \\
\hline PRODUCERS & 20 & 82 & 100 & 202 \\
NON PRODUCES & 376 & 205 & 388 & 969 \\
MISSING & 3 & 5 & 7 & 15 \\
\hline TOTAL & 399 & 292 & 495 & 1186 \\
\hline
\end{tabular}

The recent Human Development Reports note a weak relationship between the levels of low and medium HDI with development indicators (income, education and economic growth). The study findings corroborate data of UNDP:

The correlation at current levels, which contrasts with the lack of correlation in changes over time, is a "picture that reflects historical patterns, as countries that got rich were the only ones who could afford the expensive advances in the areas of health and education (p.4) ... one of the most surprising results in research (Human Development) is the lack of a significant correlation between economic growth and improvements in health and education" (p. 47) [74].

Kenny [77], also noted no correlation between indicators of income and education and is as search suggestion. In 2009 he finds a significant correlation between the generation and diffusion of new technologies and low-cost development indicators [78]. Sen [79] shows that a development approach must rely on the methodology he called Triple R. To propose a reform should make public action to reach people, families and communities to which they are designed (range). To be effective, these interventions should be comprehensive, ie have to attack all operational constraints identified (range) [80]. These actions must be consistent and influence the aspirations, goals and empower beneficiaries. These must move from passive recipients to agents of development policies (ownership) [75].

The institutions and the policy framework plays a key role in reducing the vulnerability of the population in the event of shocks caused by economic changes in the region [81]. It adds up the development of Mayer-Foulkes [82], that there is a relationship between human development and the characteristics of the region. Skoufias and others [83] showed the effectiveness of social assistance programs when they are clearly oriented. Especially the Bolsa Familia program, which contributed to the fall in inequality of health and education observed, given the growing income inequality.

Likewise, Kakwani and Son [84] argue that in Brazil, during the decade after 1995, labor markets were negatively affected, the income derived from social security and other government transfers played a crucial role 
in mitigating the effects of macroeconomic shocks. Mayer-Foulkes [82] showed that guarantees security and income transfer programs operate successfully to avoid the bad equilibrium of a poverty trap.

\section{Conclusion}

This work aimed to propose development alternatives based on the analysis of internal and external aspects that influence the smallholdings in the southeast Brazil, according to the variables of human development, income and education. The original proposal was based on the belief that the replacement of traditional crops by planting timber assumes the disappearance of small farms, the micro and small business. The owners of these lands, in a future scenario would migrate to the cities in a situation of inequality, aggravating the outskirts of the local towns. For the region, would remain the loss of culture and quality of life with the installation of pockets of poverty.

The replacement of traditional crops by planting timber assumes the disappearance of small farms, the micro and small business and its owners. In a future scenario where people migrate to the cities in a situation of inequality, aggravating the outskirts of the local towns. For the region, remain the losses of culture and quality of life with the installation of pockets of poverty. This phenomenon is accompanied by demographic, economic and epidemiological, resulting in the need to reorganize and rethink your life.

The issues of labor are the possible alternatives for the rural population of the region in the XXI century as the proposed scenario. Issues to be studied were (i) whether forestry is an activity that leads to the impoverishment of the region, (ii) whether the traditional economic activity causes the region's wealth, (iii) if the region west of Santa Catarina could be achieved by forestry. To answer these questions were formulated hypotheses that (i) there is an inverse relationship between the HDI and forestry, (ii) forestry activity is replacing the traditional economy.

The analysis of production data showed that forestry cannot study the production of an aggregated to achieve the purposes it is desired in this work. The distribution of forestry production is not uniformly distributed in southern.

The study forestry restricted to the examination of the species presented in the IBGE Census of Agriculture [12], [24], [85]. The species studied were the acacia, eucalyptus, pine american and brazilian pine. It was found that there was a concentration on the production of acacia in Rio Grande do Sul, eucalyptus production is restricted to a particular region of Santa Catarina, Rio Grande do Sul and smaller and located in Paraná. The concentration of American pine observed between Santa Catarina and Paraná. Finally with a distribution, significantly less Brazilian pine throughout the region.

The chance of advancing to the region studied forestry seems unlikely. It appears that investment in forestry is happening with funding from international investment funds. His focus is on large plantations with high productivity for application in pulp and steel. This investment is concentrated in the state of Mato Grosso do Sul given the comparative advantages of the region. The acacia plantation remains in Rio Grande do Sul is linked to the footwear industry and this depends on the production of leather that shows signs of stabilizing.

The intersection of these categorical variables with HDI development indicators, Income-Education for all variables tested, confirmed the hypothesis $H_{0}$, i.e. we cannot say from the data analysis and the existence of a HDI relationship between cultures and traditional economics.

Over the past 30 years the structures, organization of business, use of properties, combined with production practices in combination, have changed the results of production without increasing resource utilization. Agricultural production has expanded with the reduction of the deforested area and resources (land, pesticides and others). The best use of inputs has helped farmers to reduce impacts on costs.

The global investment in forestry for pulp production is directed to Brazil. This country will receive virtually all investment in planted forest in the world, given the favorable productivity. The same is observed internally to produce coal for the steel industry. This makes, or makes new investments in technology to reduce costs, or maintaining the current structure. This brings us the greatest return occurs in a plant depreciated (brownfield) or a new, built in another location (Greenfield) [86].

Also CONAB policies and other mechanisms to guarantee the producer are being implemented by both the MAP for major producers such as the MDS / MDA for small [87]. There is the concern of universities and agencies rural assistance for the proper training of producers.

As the industry's traditional economic activity is concentrated in the region studied, in the case of a possible crisis will need to study to be where the migration of labor excluded because "the places most affected by the crisis are those where most of the migrants reside centers attractors "this labor [88].

According to Stiglitz, Sen and Fitoussi [88] what to measure and how to measure makes a difference to the policy, to decide what works and what does not. You cannot measure something as complex as "society" with a single measure. A number can be misleading if a measure used for many purposes, particularly as a broader measure of social performance. New metrics and new data cost much money, and depend on the 
purpose of the measure. Our discussion of the data points to the carefully studied the use of each, and the need for better selection of using metrics appropriate for different purposes.

What is not traded in markets and not captured by monetary measures, "quality of life" is present in this region. The measurement of economic performance and its accounting should also include these values. Effort is needed to try to narrow the gap between measures of economic performance and perception of widespread welfare and concern for the environment.

This reinforces the importance of the search for metrics that assess sustainability. This debate should include social values and if we are really fighting for what is important.

The principle was sought alternatives to farmers west of Santa Catarina. Actually learned from the producers and people interviewed, that to survive and thrive as entrepreneurs, i.e., the product of their land, are guided by trust and responsibility. Responsibilities as Individual, society, species, the other, the company, production, market and especially with the blessed land, dear and beloved, inseparable and interdependent relationships that make up a web of relationships and, somehow, have a valuable tool, rare, hardly imitable and irreplaceable, i.e. meet the conditions necessary to generate and sustain competitive advantages.

According to Mayer-Foulkes, the economic geography is most significant for economic development and human than any indicator or trading market [82].

It is believed that the great merit of the work was awakening to the need for more research. Not those statutory and ceremonial but those made towards the integration of teaching and research and extension.

This study did not mention, but it is of interest to study the ecological footprint of traditional economic activities in the counties producing animals and its relation to the activities of grain production.

\section{Acknowledgements:}

The authors highlight the support of their research and thanks CNPq (Brazilian National Council for Scientific and Technologic Development) for supporting thenin their research. The authors thanks Prof. PhD. Luciene S. Delazari, Cynthia R. Lima, Everton Bortolini, António Stressner, Fabio M. G, Costa, Frederico S. Novaes, Joaquim Rausis, Natanael Cardoso, mainly Moema Bassfeld (librarian) and the anonymous reviewers for their valuable comments that helped us refine our message as well improving the former draft of our paper. The responsibility for this paper is fully of the authors.

\section{References}

[1] A. Brandenburg, Agricultura familiar, INGs e desenvolvimento sustentável (Curitiba,PR: Ed. UFPR, 1999).

[2] J. E. Veiga, O Brasil rural precisa de uma estratégia de desenvolvimento.Estudos Avançados 15 (43), $2001,101-119$.

[3] C. E. Guanziroli, S. E. C. S. Cardim, G. A. Bittencourt, and A. D. Sabbato, Novo retrato da agricultura familiar: o Brasil redescoberto (Brasília, DF:FAO/INCRA, 2000).

[4] C. E. Guanziroli, A. Romeiro, and A. Buaimin, Agricultura familiar e Reforma Agrária no século XXI (Rio de Janeiro, DF: Garamond, 2001).

[5] J. A. F. A. Filho, M. G. da Silva, M. Estudo de Potencialidades Econômicas. (Belo Horizonte, MG: Ministério do Desenvolvimento Agrário - MDA, 2009).

[6] O. M. P.Silva and, L. Panhoca, A contribuição da vulnerabilidade na determinação do índice de desenvolvimento humano: estudando o estado de Santa Catarina. Ciência \& Saúde Coletiva, 12 (5), 2007, 1209-1219.

[7] L.Panhoca. L.L.Diniz Filho, L.B.Almeida. Reflections for sustainable development: Forestry industry insouthern Brazil. Journal of Computer Engineering. X, (X), Jan. - Feb. 2013, 01-13

[8] D. Dosza, R. R. Navarro, L. Panhoca, and L. M. Carneiro, A organização de produtores rurais como fator de promoção de desenvolvimento (Fóz do Iguaçu, PR: UNIOESTE, 2011).

[9] O. M. P Silva,. et al. The accountancy of the potential income lost due premature death: differences determined by gender. Revista de Contabilidade e Controladoria, 1(1), 2009, 1-16.

[10] W. M. Adams, Green development: environment and sustainability in a developing world.(New York,NY: Routledge, 2008).

[11] D. J. Hogan, Dinâmica populacional e mudança ambiental: cenários para o desenvolvimento brasileiro (Campinas, SP: UNICAMP, 2007).

[12] IBGE, Censo Agropecuário 2006: Brasil grandes regiões e unidades da federação (Rio de Janeiro, RJ: Ministério do Planejamento, Orçamento e Gestão, 2009).

[13] M. V. A. Finco, Pobreza rural e degradação ambiental: uma refutação da hipótese do círculo vicioso no Rio Grande do Sul (Porto Alegre, RG: UFRG, 2003).

[14] L. L. Diniz Filho, Os equivocos da noção de "Regiões que exploram Regiões": crítica ao conceito de transferência geográfica de valor de Edward Soja.Revista do Departamento de Geografia, 13(1), 2011, 165-186.

[15] PNUD, Atlas do Desenvolvimento Humano no Brasil (Brasilia, DF: PNUD, 2010).

[16] R. A. Goldberg, Agribusiness coordination: a systems approach to the wheat, soybean and Florida orange economics.(Boston, MA: Harvard University, 1968).

[17] A. M. Buainaim, A. Romeiro, A agricultura familiar no Brasil: agricultura familiar e sistemas de produção (Brasilia, DF: INCRA, 2010).

[18] J. A. Schumpeter, Teoria do desenvolvimento econômico: uma investigação sobre lucros, capital, crédito, juro e o ciclo econômico !Sao Paulo, SP: Nova Cultural, 1997).

[19] D. Harvey, Condição pós-moderna (São Paulo, SP: Loyola, 1993).

[20] M. Cimoli, G. Porcile, Sources of learning paths and technological capabilities: an introductory roadmap of development processes. Economics of Innovation and New Technology, 18(7), 2009, 675 - 694

[21] S. R. Khandker, G. B. Koolwal, and H. A. Samad, H. A. Handbook on impact evaluation: quantitative methods and practices (Whashington, DC: The World Bank, 2010). 
[22] M. Cimoli, G. Porcile, Volatility and crisis in catching-up economies: industrial path-through under the stickiness of the technological capabilities and "the red queen effect (Santiago, Chile: CEPAL,2008)

[23] A. C. P. Benedetti, Modelagem dinâmica para simulação de mudanças na cobertura florestal das serras do sudeste e campanha meridional do Rio Grande do Sul,.doctoral Diss., Programa de Pós-Graduação em Engenharia Florestal, Santa Maira, RS, 2010.

[24] IBGE,Manual do Recenseador (Rio de Janeiro, RJ:IBGE, 2006).

[25] S. P. Aldrich, et al. Land-cover and land-use change in the brazilian amazon: smallholders, ranchers, and frontier stratification. Economic Geography, 102(1), 2006, 265-288.

[26] A. Marshall, Principios de economia: tratado introdutorio (São Paulo, SP: Nova Cultural, 1985).

[27] B. J. Alencar, A análise multivariada aplicada ao tratamento da informação espacial: uma abordagem matemático-computacional em análise de agrupamentos e análise de componentes principais, doctoral diss., Pontifícia Universidade Católica de Minas Gerais, Belo Horizonte, MG,2009.

[28] B. T McCann, T. B. Folta, Location matters: where we have been and where we might go in where we might go in agglomeration research. Journal of Management, 34(3), 2008, 532-565.

[29] R. A. Johnson, D. W. Wichern, Applied multivariate statistical analysis (New Tork, NY: Prentice-Hal, 2002).

[30] S. Kamath, J. Agrawal, and C. Kris, Explaining geographic cluster success - the GEMS modelajes. The American Journal of Economics and Sociology, 71(1), 2012, 184-214.

[31] S. A. Mingoti, Análise de dados através de métodos de estatística multivariada: Uma abordagem aplicada (Belo Horizonte, MG: UFMG, 2005).

[32] R. M. M. Araújo, Análise de componentes principais e análise de agrupamentos - aplicação em variáveis de Educação e Renda no Estado de Pernambuco. e-Xacta, 3(1), 2010, 1-10.

[33] L. P. Fávaro, P. S. Belfiore, P. L. Silva, and B. L. Chan, Análise de dados: modelagem multivariada para tomada de decisões (Rio de Janeiro, RJ: Elsevier, 2009).

[34] A. Favareto, A., M. Schroder, Do território como "ator" ao território como "campo":Uma análise da introdução da abordagem territorial na política de desenvolvimento rural no Brasil, Proc. XLV Congresso da SOBER, Brasilia, DF, 2007, 1-27.

[35] J. F. Hair Jr., R. E. Anderson, R. L. Tathan, and W. C. Black, Análise multivariada de dados (Porto Alegre, RS: Bookman, 2005).

[36] R. J. Fraga, Conflitos e incertezas na tomada de decisão coletiva: um novo olhar sobre a ampliação dos limites da racionalidade, doctoral diss., Pontifícia universidade Catórlica do Paraná, Curitiba, PR,2009..

[37] POPPER, K. A lógica da pesquisa científica(São Paulo, SP: Cultrix, 2009).

[38] J. A. C. Oberto, O desempenho organizacional numa perspectiva de integração das distintas interfaces em competição: casos do setor vitivinicola do Alemtejo (Lisboa, PT: Universidade Tecnica de Lisboa, 2006).

[39] A. Svendsen, The stakeholder strategy: profiting from collaborative business relationships. (San Francisco, CA: Berrett-Koehler, 1998).

[40] T. Penrose, The theory of the growth of the firm (New York, NY: Oxford University Press, 1995).

[41] B. Wernerfelt, A resource-based view of the firm. Strategic Management Journal, 5(2), 1984, 171-180.

[42] J. B. Barney, D. N. Clark, Resource-based theory: creating and sustaining competitive advantage (Oxford, UK: Oxford University Press, 2007).

[43] MDA. Plano territorial de desenvolvimento rural sustentável: guia para planejamento (Brasília, DF: Secretaria de Desenvolvimento Territorial, 2005).

[44] M. Santos, Técnica espaço tempo: globalização e meio técnico-científico informacional (São Paulo, SP: HUCITEC, 1994).

[45] M. Santos, Para uma geografia nova: da crítica da geografia a uma nova geografia crítica (São Paulo: EDUSP/HUCITEC, 1978).

[46] P. J. Neary, Of hype and hyperbolas: introducing the new economic (Oxford, UK: Oxford University Press, 2000).

[47] D. Jeffrey D. Corbin, and K. D. Holl, Applied nucleation as a forest restoration strategy. Forest Ecology and Management, 265(1), $2012,37-46$.

[48] E. Morin, Introdução ao pensamento complexo(Lisboa, PT: Sulina, 2011).

[49] F. Arilson, M. Schroder, Do território como "ator" ao território como "campo": uma análise da introdução da abordagem territorial na política de desenvolvimento rural no Brasil (Londrina, PR: Sociedade Brasileira de Economia, Administração e Sociologia Rural - SOBER, 2007).

[50] FAO, State of the World's Forests 2011 (Roma, IT: United Nations, 2011).

[51] FAO,Global Forest Resources Assessment Update 2005: Terms and definitions (Rome, IT: FAO United Nations, 2004).

[52] MAPA. Projeções do Agronegócio: Brasil 2009/10 a 2019/20 (Brasila, DF: Ministério da Agricultura, Pecuária e Abastecimento, 2010).

[53] MAPA. Brasil projeções do agronegócio: 2010/2011 a 2020/2021 (Brasilia, DF: Ministério da Agricultura, Pecuária e abastecimento, 2011).

[54] ABRAF,Anuário Estatístico ABRAF 2011 (Brasília, DF: ABRAF - Associação Brasileira de Produtores de Florestas Plantadas, 2011).

[55] J. B. Mendes, Estratégias e mecanismos fiinanceiros para florestas plantadas (Curitiba, PR:2005).

[56] A. Fanzeres, R. Alves, Temas conflituosos relacionados à expansão da base florestal plantada e definição de estratégias para minimização dos conflitos identificado (Brasília,DF: MMA/FAO, 2005).

[57] P.A. Alves, L. F. Mattei, Migrações no oeste catarinense: História e elementos explicativos, Proc. XV Encontro Nacional de Estudos Populacionais: Desafios e oportunidades do crescimento zero, Caxambú, MG, 1990, 18-22.

[58] R. V. Alves, Estudo de caso da comercialização de produtos florestais não madeireiros (PFNM) como subsídio para a restauração florestal, master diss., Universidade Federal de Viçosa, Viçosa, MG: 2010.

[59] SFB, Florestas do Brasil em resumo - 2010 (Brasilia, DF: Serviço Florestal Brasileiro, 2010).

[60] D. Zanchetta, F. V. Diniz, Estudo da contaminação biológica por Pinus spp. em três diferentes áreas na estação ecológica de Itirapina (SP, Brasil), Revista do Instituto Florestal, 18(1), 2006, 1-14.

[61] J. Y. Shimizu, Pinus na silvicultura brasileira (Viçosa, MG: Editora UFV, 2008).

[62] T. M. Almeida, A. M. Santos, M. S. Moreau, and M. F. Pires, Reorganização socioeconômica no extremo sul da bahia decorrente da introdução da cultura do eucalipto, Sociedade e Natureza, 20(2), 2008, 5-18.

[63] A. J. Martini, O plantador de Eucaliptos: a questão da preservação florestal no Brasil e o resgate documental do legado de Edmundo Navarro de Adrade, doctoral diss., Universidade de São Paulo, São Apulo, SP, 2004.

[64] VENCOVSKY, V. P. Ferrovia e logística do agronegócio globalizado: avaliação das políticas públicas e privadas do sistema ferroviário brasileiro, doctoral diss., Instituto de Geociências da UNICAMP, Campinas, SP,2011.

[65] S. Ahrens, A concepção de regimes de manejo para plantações de pinus spp. no Brasil (Curitiba, PR: EMBRAPA Florestas. 1987). 
[66] J. Santini, C. R. Haselein, D. A. Gatto, Análise comparativa das propriedades físicas e mecânicas da madeira de três coníferas de florestas plantadas. Ciência Florestal, 10(1), 2000, 85-93.

[67] IBAMA, Desmatamento: Como evitar o desmatamento clandestino(Brasilia, DF: IBAMA, 2011).

[68] BRACELPA, Dados do setor - 2011 São Paulo, SP: BRACELPA, 2011).

[69] F. M. Filho, Agentes sociais no Paraná.Economia \& Tecnologia, 22( jul/set), 2010, 7-33.

[70] N. Woloszyn, Em busca da terra: Colonização e exploração de madeiras no Oeste Catarinense. Linhas, 8(1), 2007,1-16.

[71] M. D. Silva, Os cultivos florestais do pampa, no sul do Rio Grande do Sul: desafios, perdas e perspectivas frente ao avanço de novas fronteiras agrícolas. Floresta, 42(1), 2012, 215-226.

[72] T. Coletti, H. N. Lins, A suinocultura no vértice das relações entre agroindústria e agricultura familiar no oeste de Santa Catarina. Ensaios FEE, 32(11), 2011. 339-360.

[74] PNUD. RDH 2007/2008 - Combater as alterações climáticas: Solidariedade humana num mundo dividido (New York, NY: PNUD, 2007).

[74] PNUD. RDH 2010 - A Verdadeira Riqueza das Nações: Vias para o Desenvolvimento Humano (New York: PNUD, 2010).

[75] PNUD.Informe Regional sobre Desarrollo Humano para América Latina y el Caribe 2010: Actuar sobre el futuro: romper la transmisión intergeneracional de la desigualdad (New York, NY: PNUD, 2010).

[76] J.W. Creswell, Qualitative inquiry and research design: choosing among five traditions (Thousand Oaks, CA: SAGE, 1998).

[77] C. Kenny, The lobal expansion of primary education (New York, NY: Charles Kenny Pub. 2008).

[78] C. Kenny, There's more to life than money: exploring the levels/growth paradox in income and health. Journal of International Development, 21(1), 2009. 24-41.

[79] A. Sen, The Three R's of Reform, Economic and Political Weekly, XL(19), 2005.

[80] S. Anand, A. Sen The income component of the Human Development Index (Whashington, DC: Routledge, 2000).

[81] M. Nissanke, E. Thorbecke, E. The impact of globalization on the poor in Latin America. The Journal of the Latin American and Caribbean Economic Association, 9(1), 2008, 20-78.

[82] D. Mayer-Foulkes, Divergences and convergences in human development (New York, NY: PNUD, 2010).

[83] E. Skoufias, k. Lindert, J. Shapiro, Globalization and the role of public transfers in redistributing income in Latin America and the Caribbean (Helsinki,FI: Leibniz Information Centre for Economics, 2009).

[84] N. Kakwani, H. Son, Poverty equivalent growth rate.The Review of Income and Wealth, 54(4), 2008. 643-655.

[85] IBGE, Manual técnico de uso da terra (Rio de janeiro, RJ: Diretoria de Geociências - Coordenação de Recursos Naturais e Estudos Ambientais, 2006).

[86] U. Ferber, D. Grimski, K. Millar,and P. U. Nathanail, Sustainable brownfield regeneration cabernet network report.(Nottingham, EN: NU Press, 2006).

[87] CONAB, Corredores de escoamento da produção agrícola: corredor da rodovia BR-163 (Brasília, DF: CONAB2007).

[88] PNUD. RDH 2009 - Ultrapassar barreiras: mobilidade e desenvolvimento humanos (New York, NY: PNUD, 2009).

[89] J. E. Stiglitz, A. Sen, J. P. Fitoussi, The measurement of economic performance and social progress revisited: reflections and overview (Paris,FR: WB,2009). 